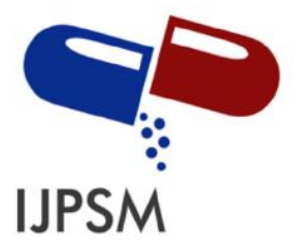

Rekha Gour, Int. Journal of Pharmaceutical Sciences and Medicine (IJPSM), Vol.6 Issue. 4, April- 2021, pg. 25-41

ISSN: 2519-9889

Impact Factor: 3.426

\title{
Boerhaavia Diffusa Linn \\ Plant: A Review - One Plant with Many Therapeutic Uses
}

\author{
Rekha Gour* \\ BM College of Pharmaceutical Education and Research, Khandwa Road, Indore (India) \\ DOI: 10.47760/ijpsm.2021.v06i04.003
}

\begin{abstract}
*Corresponding Author: Ms. Rekha Gour
Assistant Professor, BM College of Pharmaceutical Education and Research, Khandwa Road, Indore (India) 452020.

E- mail address - gourrekha4@gmail.com
\end{abstract}

\begin{abstract}
Today's world is full of huge numbers of different diseases because of our hasty schedule, and to treatment of those diseases, a huge number of medicines are taken every day to control and cure those diseases. Therefore, willingly or unwillingly, we are required to accumulate a large amount of chemicals which are lethal and unsafe for our body. Consequently, these stored chemicals produce another disease in our body, and to alleviate it, another medicine is needed which adds up more poisonous chemicals which were previously stored in our body. For this reason, the uses of natural or herbal medicines are increasing day by day due to their biodegradable nature. Boerhaavia diffusa commonly known as punarnava is a perennial herbaceous plant belonging to family Nyctaginaceae widely studied and has a long history of therapeutic uses by the indigenous and tribal people and also in Ayurvedic and Unani medicines. The chemical presents in the whole plant of Boerhaavia diffusa L. which makes it as outstandingly useful plant is now been traced out. Now, it is regarded as anti-inflammatory, antioxidant, antiaging, anticancerous, antibacterial, antistress, hepatoprotective and antidiabetic compound. Its biological used as a kidney and heart tonic and also to treat general fever, jaundice, obesity, asthma and to kill intestinal worms. The present paper provides a detailed account of therapeutic uses of whole plant of Boerhaavia diffusa linn. In this review, we will try to discuss the multifunctional uses of the plant and also we will try to summarize the innovative research on this plant.
\end{abstract}

Keywords: Boerhaavia diffusa L., Phytochemicals, Pharmacological properties, Ethanobotanical uses, Diseases, Ayurveda. 


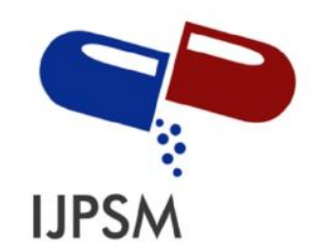

\section{Rekha Gour, Int. Journal of Pharmaceutical Sciences and Medicine (IJPSM), Vol.6 Issue. 4, April- 2021, pg. 25-41}

ISSN: 2519-9889

Impact Factor: 3.426

\section{INTRODUCTION}

There are different types of herbs useful for the prevention of the diseases that affect the various organs in the animals as well as human beings. The herbs are the initial steps for the advancement of the bioactive molecules of the drugs and its developments. The property of herbs is that it is not contain the useful contain there are harmful contain also having in the herbs. Indigenous plants are the natural inhabitants, as they are naturally occurring plants. It's essential to save indigenous species because they have often evolved to cope up with some conditions and circumstances. Indigenous species found to contain unique properties, which have been used to develop specialized drugs to save lives. It is noticeable that numerous vital herbal drugs have been developed based on ancient folk healers for treatment of ailments. Moreover, plants are the foremost line of defense for treatment of several illnesses. ${ }^{[1-6]}$

Presently, traditional herbal medicines are getting noteworthy attention in global health debate. Traditional medicines are the knowledgeable tool for the various practices as well as skills. These are based on the various theories, principles several benefits as well as their experiences related to their culture that is used for the health maintains as well as cure, diagnosis treatment, improvement, and also used for the treatment of physical and mental problems. The medicine that is traditional has been accepted by the population for the term is alternative medicine. The examples of the herbal medicines are the herbal preparations as well as herbal materials or finished products that are the part of the active portion of the plants. ${ }^{[7-16]}$

Boerhaavia diffusa is the most important herb for the life, commonly known as Punarnava in Sanskrit, is an herbaceous plant of the family Nyctaginaceae. The whole plant of Boerhaavia diffusa and its specific parts i.e. leaves, stem, and roots are known to have medicinal properties and have a long history of traditional use by indigenous and tribal people in India and is used throughout India. The curative value of Boerhaavia diffusa linn or punarnava in the management of a various number of clinical diseases is proved in Charaka Samhita, Sushruta Samhita and Ayurveda. Boerhaavia diffusa linn has several ethanobotanical uses such as the leaves are used as vegetable and the roots juice is used to cure asthma, urinary disorders, leukorrhea, rheumatism, and encephalitis. Boerhaavia diffusa is a chief medicinal plant of Kumaun Himalaya, have different pharmacological activities and used as a medicine in Ayurvedic, Unani, Siddha and Homoeopathy Systems. Boerhaavia diffusa plant was named in honor of Hermann Boerhaave, a well-known Dutch physician of the 18th century. The plant of Boerhaavia diffusa is mentioned in the Atharvaveda with the name 'Punarnava', because the top of the plant dries up for the period of the summer season and regenerates again during the rainy season. It is called as Punarnava (Punar + nava) because of Punar means - once again, Nava means - becoming new. This is also known as spiderlings as this plant grows low and spreads like spider. ${ }^{[17-25]}$ 


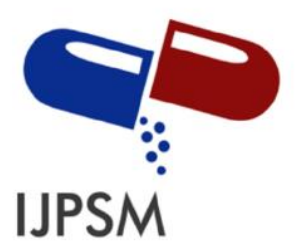

Rekha Gour, Int. Journal of Pharmaceutical Sciences and Medicine (IJPSM), Vol.6 Issue. 4, April- 2021,pg. 25-41

ISSN: 2519-9889

Impact Factor: 3.426
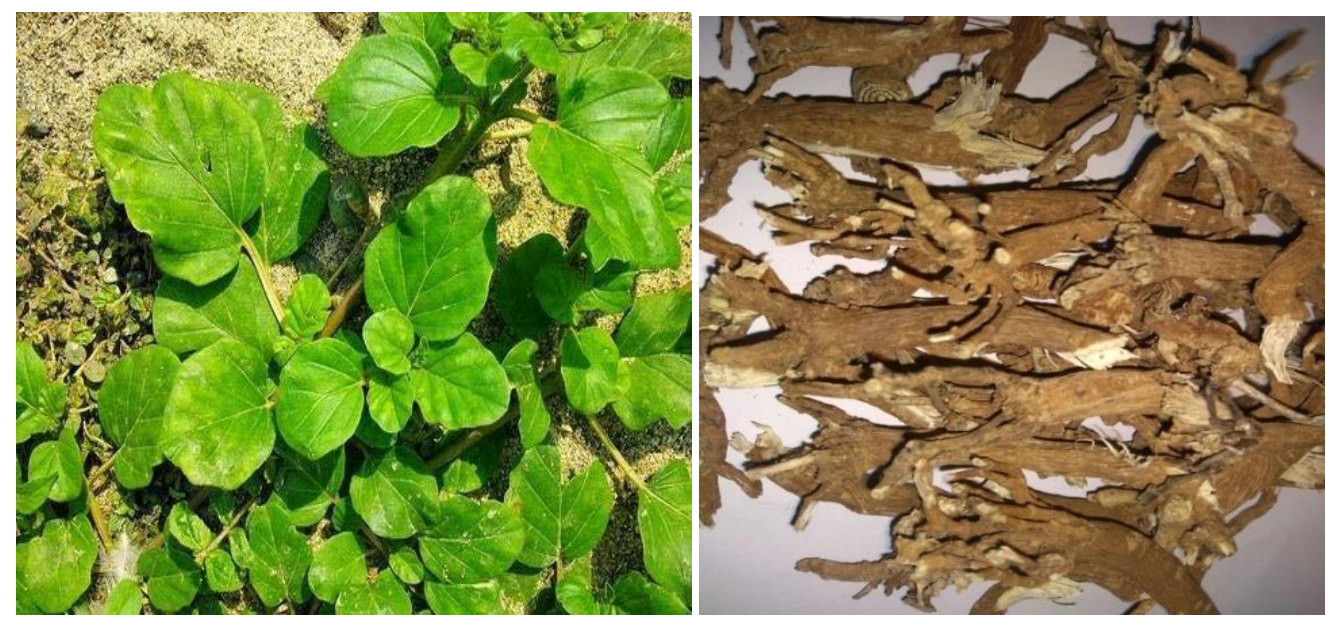

Figure No.1: Representation Photograph of Boerhaavia diffusa leaves and roots.

\section{Taxonomical Classification: -}

$\begin{array}{ll}\text { Kingdom: } & \text { Plantae } \\ \text { Subkingdom: } & \text { Tracheobionta } \\ \text { Superdivision: } & \text { Spermatophyta } \\ \text { Division: } & \text { Magnoliophyta } \\ \text { Class: } & \text { Magnoliopsida } \\ \text { Subclass: } & \text { Caryophyllidae } \\ \text { Order: } & \text { Caryophyllales } \\ \text { Family: } & \text { Nyctaginaceae } \\ \text { Genus: } & \text { Boerhaavia L. } \\ \text { Species: } & \text { Boerhaavia diffusa L. }\end{array}$

Scientific Name: Boerhaavia diffusa Linn.

Family Name: Hog weed, Horse Purslane.

Useful Parts: Roots, leaves and seeds.

Names in Different Languages (Vernacular Name): -

Sanskrit: Kahtilla, Sophaghni, Varshabhu, Punarnava, Raktakanda, Shothaghni,

Hindi: Gadahpurna, Lalpunarnava, Snathikari, Biskhafra, Beshakapori

Bengali: Raktapunarnava, Punurnava

English: Horse Purslene, spreeding Hog - Weed

Assamese: RangaPunarnabha

Gujrati: Dholisaturdi, Motosatodo

Kannada: Sanadika, Kommeberu, Komma, Kommegida 


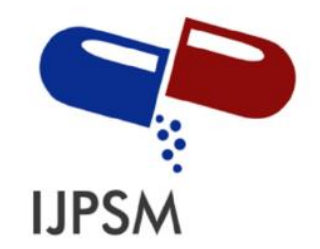

\section{Rekha Gour, Int. Journal of Pharmaceutical Sciences and Medicine (IJPSM), Vol.6 Issue. 4, April- 2021, pg. 25-41}

ISSN: 2519-9889

Impact Factor: 3.426

Kashmiri: VanjulaPunarnava

Malayalam: ChuvannaTazhutawa

Marathi: Ghetuli, Vasuchimuli, Satodimula, Punarnava, Khaparkhuti, Tambadivasu

Oriya: Lalapuiruni, Nalipuruni

Punjabi: Khattan

Tamil: $\quad$ Mukurattai (Shihappu)

Telugu: Atikamamidi, Erragalijeru, Punernava. ${ }^{[17-25]}$

\section{Geographical Distribution and Habitat:}

Boerhaavia diffusa (Nyctaginaceae) plant is a perennial species growing prostrate or ascending upward in habitats such as grasslands, agricultural fields, fallow lands, wastelands, residential compounds, ditches and marshy places during rains. Boerhaavia diffusa plant is consisting of 40 species is distributed in tropical and subtropical regions and warm climate. It is found in Pakistan, Ceylon, Australia, Sudan and Malay Peninsula, extending to China, Africa, America and Islands of the Pacific that is found in warmer parts of these countries. 6 species of Boerhaavia diffusa plant are found in India, namely Boerhaavia diffusa, B.erecta, B. rependa, B. chinensis, $B$. hirsute and $B$. rubicunda in warmer parts and all over up to 2,000 $\mathrm{m}$ altitude in the Himalayan area. The plant is also cultivated to some extent in West Bengal. ${ }^{[17-25]}$

\section{Macroscopic Characters: -}

Stems: Stems of Boerhaavia diffusa are greenish purple, stiff, slender, cylindrical and swollen at nodes or thick at the nodes, minutely pubescent or nearly glabrous. They are prostrate divaricately branched; branches from common stalk about $1 \mathrm{~m}$ in length. Stems are pale greenish below and light reddish brown above.

Roots: Roots of Boerhaavia diffusa are elongated, fusiform, tapering and somewhat tuberous or somewhat tortuous, cylindrical, $0.2-1.5 \mathrm{~cm}$ in diameter, surface soft to touch but rough due to minute longitudinal striations and root scars, fracture, short. Roots of Boerhaavia diffusa grow up vertically downwards striking deep into the soil. Old roots are often marked with knotty scars of fallen rootlets. Roots have no distinct odor; taste is slightly bitter, sweet, and pungent. They are cream or light brownish yellow, with very soft skin. ${ }^{[22-26]}$

Leaves: Leaves of Boerhaavia diffusa are contradictory in unequal pairs, ovate-oblong or sub orbicular, apex rounded or slightly pointed, base subcordate or rounded. Leaves size is larger ones $25-37 \mathrm{~mm}$ long and smaller ones 12-18 mm long and colour is green and whitish below, glabrous above. Margin entire or sub undulates, dorsal side pinkish in certain cases, thick in texture, petioles nearly as long as the blade, slender.

Flowers: Flowers of Boerhaavia diffusa are very small, lower part greenish, ovoid and upper part pink in colored, funnel-shaped, nearly sessile or shortly stalked, 10-25 cm, in small umbells, arranged on slender long stalks, 4-10 corymb, axillary and in terminal panicles, small, acute, bracteoles, perianth tube. Flowers are 


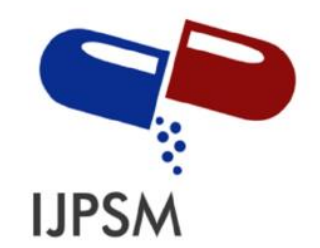

\section{Rekha Gour, Int. Journal of Pharmaceutical Sciences and Medicine (IJPSM), Vol.6 Issue. 4, April- 2021, pg. 25-41}

ISSN: 2519-9889

Impact Factor: 3.426

internally sessile in small umbels, about $10-25 \mathrm{~mm}$ in length. Fruits are one seeded nut, glandular, rounded and about $0.5 \mathrm{~cm}$ in size that is $6 \mathrm{~mm}$ long clavate, broadly and straightforwardly 5 ribbed. ${ }^{[26-30]}$

Whole plant of boerhaavia diffusa is devoid of fragrance and taste is bitter.

\section{Microscopic Structures: -}

Stem: Boerhaavia diffusa stem that is transverse section of stem illustrates epidermal layer containing uniseriate glandular trichomes and multicellular which consists of an ellipsoidal head and 9-12 stalked cells, 150-220 $\mu \mathrm{m}$ long cortex that is consists of 1-2 layers of parenchyma, endodermis indistinct, pericycle 1-2 layered and thickwalled often containing scattered isolated fibers, stele which is consisting of various small vascular bundles frequently joined simultaneously in a ring and various large vascular bundles scattered in the ground tissue, and intrafascicular cambium present.

Root: Transverse section of boerhaavia diffusa linn root illustrates a cork com posed of thin-walled agilely elongated cells with brown walls in the outer few layers and cork cambium of 1-2 layers of thin-walled cells. Secondary cortex consists of 2-3 layers of parenchymatous cells followed by cortex composed of 5-12 layers of thin-walled, oval-to-polygonal cells and several concentric bands of xylem tissue alternating with wide zone of parenchymatous tissue present below cortical regions and number of bands vary according to the thickness of root of Boerhaavia diffusa and composed of vessels, tracheids, and fibers. Vessels generally originate in clusters of 2-8 in radial rows, containing reticulate thickening, small, thick walled, tracheids and simple pits. Fiber saseptate, thick-walled, spindle shaped and elongated with pointed ends. Phloem takes place as hemispherical outer surface each group of xylem vessels and created of sieve elements and parenchyma, broad zone of parenchymatous tissue. Two successive rings of xylem elements arranged of thin-walled additional or fewer rectangular cells organized in radial rows, central areas of root of Boerhaavia diffusa occupied by main vascular bundles, many raphides of calcium oxalate in single or in group present in cortical section. Parenchymatous tissue in between xylem tissue and simple starch grains, compound containing 2-4 components originate in abundance in most of cells of cortex.

Leaves: Transverse section of Boerhaavia diffusa leaf illustrates anomocytic stomata on both the sides, several, a few short hairs, 3-4 celled that is present on the margin and on veins, palisade one layered, spongy parenchyma 2-4 layered among tiny air spaces. Idioblasts having raphides intermittently cluster crystal of calcium oxalate and orange-red resinous substance present in mesophyll. Palisade ratio 3.5-6.5, stomatal index $11-16$, and vein islet number $9-15$. $^{[26-30]}$

Phytochemistry: Phytochemicals are natural bioactive compounds found in plants, including the medicinal plants, fruits, vegetables, flowers, leaves, roots and fibers and they act as a defense system against diseases or more accurately protect plants against diseases. The therapeutic abilities, including antioxidant property, antimicrobial and anticarcinogenic properties of higher plants are due to the occurrence of secondary metabolites like flavonoids etc. The medicinal values of these plants lie in bioactive phytochemical constituents 


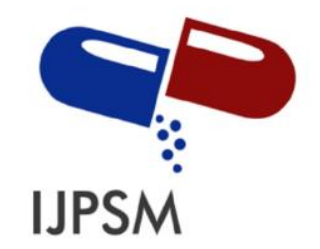

\section{Rekha Gour, Int. Journal of Pharmaceutical Sciences and Medicine (IJPSM), Vol.6 Issue. 4, April- 2021, pg. 25-41}

ISSN: 2519-9889

Impact Factor: 3.426

with the intention of produce exact physiological actions on the human and animal body. A number of the most significant bioactive phytochemical constituents are the alkaloids, glycosides, carbohydrates, flavonoids, essential oils, tannins, steroids, terpenoids and phenolic compounds. These biologically active chemical constituents recognized as secondary metabolites in medicinal plants, form the establishments of modern prescription drugs. In recent decades, there are many reports on the use of medicinal plants. From the previous studies, it was find out that the accurate amount of active chemical constituent are frequently unidentified. Therefore, it was discovered that multiple chemical constituents are generally responsible for the therapeutic effects of the plants. These multiple chemical constituents may take action synergistically and can hardly be divided into active parts. Furthermore, the herbal chemical constituents may be different depending on the harvest seasons, plant origins, drying procedure and other aspects.

The Boerhaavia diffusa linn contains a huge number of such chemical constituents as alkaloids, steroids, triterpenoids, lipids, flavonoids, lignins, carbohydrates, proteins, and glycoproteins. Punarnava also have been isolated such chemical constituents including Boeravinone A-F, hypoxanthine 9-Larabinofuranoside, ursolic acid, punarnavoside, lirodendrin, and a glycoprotein having a molecular weight of $16-20 \mathrm{kDa}$, considered in detail for their biological activity. Punarnavine $\mathrm{C}_{17} \mathrm{H}_{22} \mathrm{~N}_{2} \mathrm{O}$ m. p. $236-237^{\circ} \mathrm{C}$. Boerhaavia diffusa linn also contains 2- $\alpha$-sitosterol, palmitic acid, arachidic acid, $\beta$-Sitosterol, ester of $\beta$-sitosterol, hexacosonoic, stearic, tetracosanoic, urosilic acid, $\beta$-Ecdysone, triacontanol, Hentriacontane etc. The herb and roots of punarnava are rich in proteins and fats. The herb contains 15 amino acids, with 6 essential amino acids, whereas the root contains 14 amino acids, as well as 7 essential amino acids. Plant contained large quantities of potassium nitrate, besides punarnavine. ${ }^{[17-30]}$

\section{Chemical constituents of Root: -}

The root contains 14 amino acids, including 7 essential amino acids (total $11.54 \%$ ). These are: alanine 1.18; arginine 0.75 ; aspartic acid 0.95 ; glutamic acid 1.45 ; leucine 0.88 ; methionine 0.45 ; ornithine 0.96 ; phenylalanine 0.71 ; proline 0.5 ; serine 0.85 ; threonine 0.79 ; tryptophan 0.65 ; tyrosine 0.72 ; asparagines 0.0 ; glycine 0.0 and valine $0.75 \% 29$. The root of Boerhaavia diffusa linn was reported to yield a new dihydrofuranoxanthone and c-methyl flavone designated as borhavine and borhavone respectively. Other four new compounds have been isolated as boerhavisterol, boerhavilanostenyl benzoate, boerhadiffusene, diffusarotenoid and a known rotenoid, boeravinone were also isolated from its roots. Roots presented fewer flavonoid derivatives quercetin-3-O-robinobioside and eupalitin-3-O-galactosyl (1-2)-glucoside, but exhibited one phenolic acid, caffeoyltartaric acid, which was absent in leaves. ${ }^{[17-30]}$ 


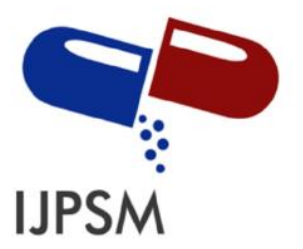

Rekha Gour, Int. Journal of Pharmaceutical Sciences and Medicine (IJPSM), Vol.6 Issue. 4, April- 2021, pg. 25-41

ISSN: 2519-9889

Impact Factor: 3.426

Table 1: Chemical constituents isolated from different parts of Boerhaavia diffusa linn.

\begin{tabular}{|c|c|c|c|}
\hline Chemical classes & Name of compounds & Activity reported & Plant parts \\
\hline Phenolic glycoside & Punarnavoside & \multirow[t]{3}{*}{ Antifibrinolytic } & \multirow[t]{3}{*}{ Roots } \\
\hline C-Methyl flavone & Borhaavone & & \\
\hline Isoflavone & 2-O-Methyl abronisoflavone & & \\
\hline Isoflavone & Quercetin, kaempferol & \multirow[t]{3}{*}{ Antifibrinolytic } & \multirow[t]{3}{*}{ Leaves } \\
\hline Acids & $\begin{array}{l}\text { Tetracosanoic, hexacosonoic, stearic, palmitic, } \\
\text { arachidic acids. } \\
\text { Boerhavin and boerhaavic acid. }\end{array}$ & & \\
\hline $\begin{array}{l}\text { Flavonoid } \\
\text { Glycoside }\end{array}$ & $\begin{array}{l}\text { 3,4-Dihydroxy-5-methoxycinnamoyl rhamnoside, } \\
\text { Quercetin 3-O-rhamnosyl }(1 \rightarrow 6) \text {, galactoside } \\
\text { (quercetin 3-O-robinobioside), Eupalitin 3-O- } \\
\text { galactosyl }(1 \rightarrow 2 \text { ) glucoside, Kaempferol 3-O } \\
\text { robinobioside, Eupalitin-3-O- } \beta-D \text { - } \\
\text { galactopyranoside. }\end{array}$ & & \\
\hline Phenolic acid & Trans-caftaric acid & \multirow[t]{2}{*}{ Antifibrinolytic } & \multirow[t]{2}{*}{ Roots } \\
\hline \multirow{3}{*}{ Rotenoids } & $\begin{array}{l}\text { Boeravinones A, B, C, D, E, F. } \\
\text { Boeravinones G, H. } \\
\text { Boeravinones I, J. }\end{array}$ & & \\
\hline & $\begin{array}{l}\text { 9-O-Methyl-10-hydroxy coccineone E. } \\
\text { Diffusarotenoid. }\end{array}$ & Anticancer & Roots \\
\hline & $\begin{array}{l}\text { 6-O-Demethyl-boeravinone } \mathrm{H} \text {. } \\
\text { 10-Demethyl boeravinone C. } \\
\text { Coccineones E, B. } \\
\text { Boeravinones M, P,Q, R, S. }\end{array}$ & Spasmolytic & Roots \\
\hline Xanthone & Boerhavine & Spasmolytic & Roots \\
\hline Lignan & $\begin{array}{l}\text { Liriodendrin, Syringaresinol mono- } \beta-D- \\
\text { glucoside. }\end{array}$ & $\begin{array}{l}\mathrm{Ca}^{+} \text {channel } \\
\text { antagonist }\end{array}$ & Roots \\
\hline Purine nucleoside & Hypoxanthine-9-L-arabinofuranoside & Cardiotonic & Roots \\
\hline Sterol & Boerhavisterol & Cardiotonic & Roots \\
\hline
\end{tabular}




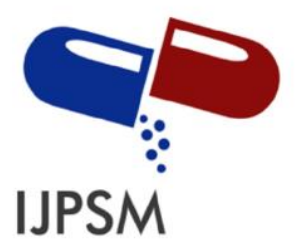

\section{Rekha Gour, Int. Journal of Pharmaceutical Sciences and Medicine (IJPSM), Vol.6 Issue. 4, April- 2021, pg. 25-41}

ISSN: 2519-9889

Impact Factor: 3.426

\begin{tabular}{|c|c|c|c|}
\hline Sterol ester & Boerhavilanostenyl benzoate & Cardiotonic & Roots \\
\hline Ecdysteroid & $\beta$-Ecdysone & \multirow{4}{*}{$\begin{array}{l}\text { Increases protein } \\
\text { synthesis, } \\
\text { antidepressant, } \\
\text { antistress and } \\
\text { immunomodulation } \\
\text {, } \\
\text { antihyperglycemic, } \\
\text { hepatoprotective }\end{array}$} & \multirow[t]{4}{*}{ Roots } \\
\hline Fatty acid & Triacont-24-en-1-oic acid & & \\
\hline Hydrocarbons & Boerhadiffusene & & \\
\hline Lipids & $\begin{array}{l}\text { 5-methyleicos-4-ene, } \\
\text { Eicos-4-ene, } \\
\text { 4-methyloctadec-3-ene, } \\
\text { 4-methylnonadecylbenzene. }\end{array}$ & & \\
\hline
\end{tabular}

Adulterants and Substitutes: Boerhaavia diffusa Linn (Raktapunarnava) are frequently adulterated with Trianthema portulacastrum Linn which is market samples. The two different Ayurvedic drugs punarnava and Varshabhu possibly that are the two different plant sources with similar therapeutic effects. The two species differ widely in their stomatal indices and palisade ratios, Trianthema portulacastrum possessing higher values. [17-20]

Ethanobotanical uses: - Boerhaavia diffusa is a very popular medicinal plant In India, known as 'Punarnava'; particularly plant parts as the leaves, seeds and roots are used. The root of Boerhaavia diffusa is registered in the Indian Pharmacopoeia. Plant parts of punarnava are used as a Stomach disorder, Reduces cough, cardio tonic, anasarca, hepatoprotective, ascites, laxative, diuretic, anthelmintic and febrifuge, healing power and curative properties, expectorant and as an emetic and purgative. As diuretic and natriuretic agents it is useful in treatment of diabetes insipidus, nephrolithiasis, strangury, Oliguria, jaundice, poisoning, enlarged spleen, glaucoma, gonorrhoea, congestive heart failure, Mountain sickness and other internal inflammations. In moderate doses it is successful in asthma. A decoction of the roots of punarnava is also useful to treat corneal ulcers and night blindness. The boiled roots of Boerhaavia diffusa Linn are useful to ulcers, abscesses and to aid in the extraction of Guinea worm in tropical Africa region. A decoction of the aerial parts is also used to manage gastrointestinal pains, convulsions, and intestinal worms. The seeds of punarnava are made into cakes that are cooked and eaten as a remedy for dysentery in Mauritania and also in west Bengal, Boerhaavia diffusa herb is cooked and eaten as a vegetable. A decoction of the root is also taken to treat heart troubles, palpitations and jaundice. Immunomodulatory Activity: Sumanth and coworker compared the effect of BD with ashwagandha and identify an increase in total swimming time in mice when fed with alcoholic extract. (Whitehouse, 1996; Mudgal, 1975; Shah et al., 1983; Jain and Khanna, 1989; Khare, 2004; Singh and Dey, 2005). Burkill, 1997; Neuwinger, 2000; Gupta et al., 1962; Gaitonde et al., 1974; Nadkarni, 1976; Anand, 1995; Mitra and Gupta, 


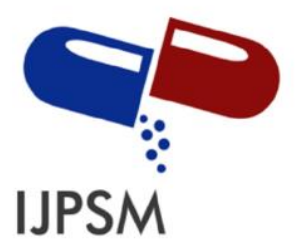

\section{Rekha Gour, Int. Journal of Pharmaceutical Sciences and Medicine (IJPSM), Vol.6 Issue. 4, April- 2021,pg. 25-41}

ISSN: 2519-9889

Impact Factor: 3.426

1997; Database entry for Erva Tostao - Boerhaavia diffusa - htm;www.Rain-tree.com; www.allayurveda.com/herb; www. Protabase Record.htm).

Table 2: Ethno medical uses of Boerhaavia Diffusa linn by various countries.

\begin{tabular}{|c|c|}
\hline Name of the Country & Ethno Medical Uses \\
\hline Brazils & $\begin{array}{l}\text { Used for kidney stones, beri-beri, gallstones, bile insufficiency, cystitis, laxative, } \\
\text { edema, liver disorders, gallbladder problems, albuminuria, gonorrhea, guinea } \\
\text { worms, urinary disorders, hepatitis, hypertension, jaundice, nephritis, renal } \\
\text { disorders, sclerosis, snakebite, spleen enlarged, urinary retention. }\end{array}$ \\
\hline Guatemala & Used for erysipelas, guinea worms. \\
\hline India & $\begin{array}{l}\text { Used for urinary disorders, weakness, abdominal pain, impotence, anemia, } \\
\text { ascites, asthma, blood purification, anasarca, hepatoprotective, cancer, cataracts, } \\
\text { childbirth, laxative, cholera, constipation, cough, debility, as a wound healer, } \\
\text { digestive sluggishness, dropsy (swelling in tissue), dyspepsia, edema, eye } \\
\text { problems, fever, gonorrhea, ascites, guinea worms, heart disease, hemorrhages } \\
\text { (childbirth and thoracic), hemorrhoids, internal inflammation, internal parasites, } \\
\text { jaundice, renal disease, renal stones, lactation relieve, hepatic disorders, liver } \\
\text { support, menstrual disease, rheumatism, snakebite, splenomegaly and as a diuretic } \\
\text { and expectorant. }\end{array}$ \\
\hline Iran & $\begin{array}{l}\text { Used for edema, poisoning, gonorrhea, hives, intestinal gas, jaundice, joint pain, } \\
\text { ascites, lumbago, glomerular nephritis, and as an appetite stimulant, anasarca, } \\
\text { diuretic and expectorant. }\end{array}$ \\
\hline Nigeria & $\begin{array}{l}\text { Used for asthma, boils, renal insufficiency, convulsions, abscesses, epilepsy, } \\
\text { fever, jaundice, guinea worms, and as an expectorant and laxative. }\end{array}$ \\
\hline West Africa & $\begin{array}{l}\text { Used for guinea worms, urinary disorders, menstrual irregularities, abortion and as } \\
\text { an aphrodisiac. }\end{array}$ \\
\hline Philippinese & Used for diuretic, fever, purgative and vermifuge. \\
\hline Ghana & Used for asthma and Boils. \\
\hline Elsewhere & Used for childbirth, guinea worms, jaundice, sterility, yaws. \\
\hline
\end{tabular}

Pharmacological activity: - The plant has gained lot of importance in the field of phytochemistry because of its various pharmacological and biological activities such as immunomodulatory effects, immunosuppressive 


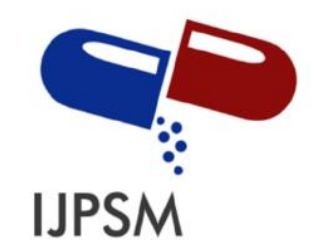

\section{Rekha Gour, Int. Journal of Pharmaceutical Sciences and Medicine (IJPSM), Vol.6 Issue. 4, April- 2021, pg. 25-41}

ISSN: 2519-9889

Impact Factor: 3.426

activity, antimetastatic activity, antioxidant activity, antidiabetic activity antiproliferative and antiestrogenic activity, analgesic and anti-inflammatory activity, antibacterial activity, antistress and adoptogenic activity, antilympho proliferative activity, nitric oxide scavenging activity, hepatoprotective activity, anti-viral activity, bronchial asthma, anti fibrinolytic activity, chemopreventive action, genetic diversity analysis, anticonvulsant activity. ${ }^{[31-52]}$

Antidiabetic activity: - This study was evaluated the effects of aqueous extract of Boerhaavia diffusa Linn leaves $(200 \mathrm{mg} / \mathrm{kg}$ wt.) for 4 weeks daily oral administration on blood glucose concentration and hepatic enzymes in normal and alloxan induced diabetic albino wistar rats. Normal and diabetic rats treated with aqueous leaves extract of Boerhaavia diffusa Linn. were detected a significant reduce in blood glucose and significant enhance in plasma insulin levels. On the basis of previous study, Chloroform extract of Boerhaavia diffusa leaf produced dose-dependent decrease in blood glucose in streptozotocin- treatment for $48 \mathrm{~h}$ resulted in a significant enhance in the number of MCF-7 cells in the G0-G1 fraction from $69.1 \%$ to $75.8 \%$, with a reciprocal reduce of cells in all other phases indicating cell cycle detain at G0-G1 phase. Bhatia et al. (2011) has been evaluated the Antidiabetic Activity of the Alcoholic Extract of the Arial Part of Boerhaavia diffusa in Rats. This study showed that alcoholic extracts of Boerhaavia diffusa have good quality antidiabetic action in rats. Mohan Nisha et al. (2018) performed antidiabetic and antihyperlipidemic activities of whole plant of Boerhaavia erecta L. in STZ-induced type 2 diabetic Wistar rats. Krishna Murti et al. (2011) also evaluated the anti diabetic - activity of 90\% ethanolic extract of Boerhaavia diffusa roots against streptozotocin (STZ) induced experimental rats. The aim of this study was evaluated the effects of daily oral administration of $90 \%$ Ethanolic solution of Boerhaavia diffusa Linn. ${ }^{[31-32,50]}$

Antibacterial Activity: - A potent antibacterial activity against Gram-positive and Gram-negative bacteria shown by the leaves of Boerhaavia diffusa might be due to the phytochemicals present in the leaves. Ethanol extract showed inhibitory an effect on Gram-positive bacteria such as S. aureus, Bacillus subtilis, Streptococcus faecalis, and Micrococcus luteus and all Gram-negative bacteria selected for the study. Umamaheswari et al. (2010) also studied the antibacterial activity of Boerhaavia diffusa L. leaves. The antimicrobial activity of Boerhaavia diffusa L. Leaves with different solvent extracts were tested against the Gram-positive and Gramnegative bacterial strains by detecting the zone of inhibition. The ethanol extract of Boerhaavia diffusa L. leaves showed more activity against Gram-positive and Gram-negative bacteria when compared to other solvent extracts except $V$. cholerae. The results proved the existence of antibacterial activity of Boerhaavia diffusa $\mathrm{L}$. leaves extract against various human pathogenic bacteria.

Anti viral and antifungal activity: - Awasthi and Menzel (1986) reported that an extract obtained from the roots of Boerhaavia diffusa plants, inhibits the infection of several plant viruses and was tested by the agar diffusion whole method for its action on RNA-containing bacterial viruses. According to Rai and Upadhyay (1988) the leaf extract of Boerhaavia diffusa shows in vitro antifungal activity against Microsporon nanumi. ${ }^{[33]}$ 


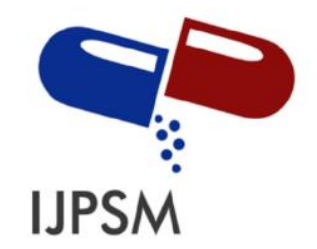

\title{
Rekha Gour, Int. Journal of Pharmaceutical Sciences and Medicine (IJPSM), Vol.6 Issue. 4, April- 2021, pg. 25-41
}

ISSN: 2519-9889

Impact Factor: 3.426

\begin{abstract}
Anti-stress Activity: - This study was investigated the effects of Hydro ethanolic extract of Boerhaavia diffusa linn and a polyherbal formulation (Punarnava mandur) PHF-09 containing Boerhaavia diffusa were compared for their anti-stress activity using cold restraint stress model. In subjecting animals, Stress was induced to cold restraint. Due to cold restraint stress, there was an imbalance in the levels of biochemical parameters such as glucose, triglycerides, cholesterol, SGOT, and SGPT which were near normalized following the administration of HEBD and PHF-09. Boerhaavia diffusa linn and a polyherbal formulation (Punarnava mandur) PHF-09 was found to have comparable significant anti-stress activity as reported in the study.
\end{abstract}

Diuretic activity: - Singh and coworkers studied the effect of aqueous ethanolic extract on E. coli-induced acute pyelonephritis in rats. The extract of Boerhaavia diffusa (50 mg/Kg p.o.) administered twice orally showed $42.85 \%$ decrease in quantity of animals and they showed signs of renal changes. Therefore, the administration of the extract of Boerhaavia diffusa $(50 \mathrm{mg} / \mathrm{Kg}$ p.o.) twice orally showed $99.09 \%$ decrease in bacterial count per $\mathrm{mL}$ of urine in rats. Other researchers as Nadkarni and Chopra reported and described the diuretic activity and alkaloidal nature of punarnavine. Patel et al. (2020) also evaluated diuretic and natriuretic activity of ethanolic extract of Boerhaavia diffusa Linn root in Albino Wistar Rats. They found that ethanolic extract of Boerhaavia diffusa Linn roots has got significant potential to be utilized as a diuretic and natriuretic substances and it may be due to presence of chemical constituents such as amino acids and alkaloids etc.

Adaptogenic/Immunomodulatory Activity: - The ethanol extracts of the roots of Boerhaavia diffusa was evaluated for antistress, adaptogenic activity in albino mice, by swim endurance test and cold restraint stress, and the ethanolic roots extract improved stress tolerance in immunomodulatory activity that was shown by enhanced carbon clearance, signifying stimulation of the reticuloendothelial system. There was enhance in DTH response to SRBC in mice, subsequently to cell-mediated immunity and signifying stimulatory effects on lymphocytes and accomplice cell types. Therefore, the aqueous extract of Boerhaavia diffusa leaves showed immunomodulatory activities and antinociceptive effect of. According to previous study by Mehrotra et al. (2002) the ethanolic extract of Boerhaavia diffusa was capable to reduce T-cell mitogen phyto haemagglutinin and concanavalin a excited proliferation of human peripheral blood mononuclear cells (PBMC).

Antimicrobial activity: - Sourav Das et al. (2012) studied the Antimicrobial activity study of ethanolic extract of Boerhaavia diffusa whole plant. They investigated ethanolic extract of Boerhaavia diffusa whole plant in 95\% ethanol possesses the significant antimicrobial activity. James Redfern et al. (2014) they also investigated the antimicrobial effects of plant material after extracting compounds using the relatively simple Soxhlet method and also studied Safety issues about The Soxhlet extraction process heats the solvent (ethanol) to boiling temperature $\left(>78^{\circ} \mathrm{C}\right)$.

Hepatoprotective Activity: - The hepatoprotective activity of roots of different diameters was collected in three seasons, rainy, summer, and winter, and examined in thioacetamide-intoxicated rats. The roots Boerhaavia diffusa has long been utilized as a popular hepatoprotective medicine for therapeutic purpose. Various extracts 


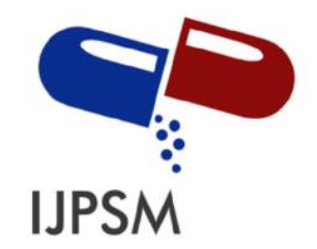

\section{Rekha Gour, Int. Journal of Pharmaceutical Sciences and Medicine (IJPSM), Vol.6 Issue. 4, April- 2021, pg. 25-41}

ISSN: 2519-9889

Impact Factor: 3.426

of the aerial part and roots of this plant showed hepatoprotection against CCl437.This plant extracts shows hepatoprotective and antioxidant activity in a dose dependent manner. Chandan, et al. (1991) evaluated that an alcoholic extract of the whole plant of Boerhaavia diffusa linn demonstrated hepatoprotective activity against experimentally induced carbon tetrachloride hepatotoxicity in rats and mice. The extract of Boerhaavia diffusa linn also produced enhances normal bile flow in rats signifying a strong choleretic property. Singh et al. (1991) reported teratogenic effects by the ethanolic extract of Boerhaavia diffusa on litter size and survival rate of foetuses in rats. Jain et al. (2013) also studied Protective effect by extract of Silybum marianum and Boerhaavia diffusa in combination against fructose induced non-alcoholic fatty liver in rats. ${ }^{[35-36]}$

Antitumor Activity: - The Cancer chemopreventive efficacy of Boerhaavia diffusa was estimated on 7, 12 dimethyl benz (a) anthracene-induced skin papillomagenesis in male Swiss albino mice. The cancer chemopreventive effectiveness of Boerhaavia diffusa was evaluated through its capability to modulate the activities of enzymes correlated with drug metabolism, and bi functional modulators decreased the availability of critical carcinogen metabolites in the epithelial stage. A significant increase in the activities of hepatic phase I and phase II system enzymes and antioxidant enzymes (glutathione peroxidase, glutathione reductase, superoxide dismutase, catalase, and glutathione level) was observed. Mehrotra and coworkers studied the immunomodulation produced Anticancer Activity.

Anticonvulsant Activity: - Anticonvulsant activity of the methanolic extract and its different fractions, i.e., liriodendronrichfraction and phenolic compound fraction was studied in pentylenetetrazol Ghosh and Rai: Multifunctional effect of Boerhaavia diffusa induced seizures. The methanolic extract of crude powder of Boerhaavia diffusa and only its liriodendron-rich portion proved a dose-dependent protection adjacent to PTZinduced convulsions. The liriodendron-rich fraction showed a significant protection against seizures induced by BAY k-8644. These findings reiterated the anticonvulsant activity of the methanolic extract of Boerhaavia diffusa roots, and also it can be concluded that the observed anticonvulsant activity was due to its calcium channel antagonistic action as this activity was determined only in the liriodendron-rich fraction, that has additionally been proved by considerable anticonvulsant activity of liriodendron-rich fraction in BAY k-8644induced seizures. ${ }^{[30]}$

Antiproliferative and Antiestrogenic Activity: - The methanol extract of Boerhaavia diffusa revealed antiproliferative and antiestrogenic properties in MCF-7 breast cancer cell lines. The methanolic extract of Boerhaavia diffusa linn showed a strong inhibitory effect on the proliferation of human breast cancer cells in vitro, and the antiestrogenic effects are mediated by ER. Phytochemical studies of Boerhaavia diffusa have showed the presence of flavonoids, amino acids, phenols, glycosides, saponins and alkaloids in methanolic extract of Boerhaavia diffusa. The antiestrogenic activity shown by the extract may be attributed to these diverse compounds. ${ }^{[31]}$ 


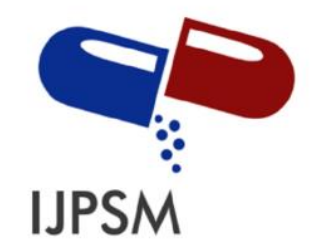

\section{Rekha Gour, Int. Journal of Pharmaceutical Sciences and Medicine (IJPSM), Vol.6 Issue. 4, April- 2021, pg. 25-41}

ISSN: 2519-9889

Impact Factor: 3.426

Cytological Activity: - The extract of Boerhaavia diffusa exhibited a strong depressive effect on the mitosis of Crinum jagus roots. Cytological Activity was conducted with the extract of Boerhaavia diffusa as well as the mitotic index of the control experiment was established to be 5.27. Therefore, a negative correlation between the concentrations of the test extracts and the mitotic indices found from their action. This points to an inhibition of mitosis through this Boerhaavia diffusa extract. Inhibition of the mitotic index increased significantly with an increase in the concentration of treatment solution of Boerhaavia diffusa.

Antihypertensive activity: - Vandana. S. Nade et al. (2015) the objective of the present study was to investigate antihypertensive potential of Boerhaavia diffusa roots in adrenaline-induced hypertension in rats. Blood pressure was measured weekly using non invasive tail cuff method. Blood pressure was determined by invasive method at the end of the study and also vascular reactivity was tested with adrenaline, noradrenaline and phenylephrine. The results suggested that the Methanolic extract of Boerhaavia diffusa possesses significant antihypertensive activity.

Analgesic and Anti-Inflammatory Activity: - Boerhaavia diffusa is used in 'Martinican folk medicine' for its analgesic and anti-inflammatory properties. Santhoshkumar muthu et al. (2014) evaluated Anti-Inflammatory Effect of Ethanolic Extract of Boerhaavia diffusa leaves in Wistar rats. They investigated of ethanolic extract of Boerhaavia diffusa reveal that the plant has wide range of phytochemical constituents and possesses free radical scavenging effect. Boerhaavia diffusa leaves also exhibit in-vitro and in-vivo anti-inflammatory potentials providing a scientific basis for anti-inflammatory effect in inflammatory diseases and support traditional claims. Gharate et al. (2013) reported anti-inflammatory, analgesic, antipyretic and antiulcer activity of Punarnavasava: an Ayurvedic formulation of Boerhaavia diffusa. Mudgal studied the anti-inflammatory effect of aqueous insoluble alcoholic extract of Boerhaavia diffusa in rats. The leaves and flower extracts have shown antiinflammatory activity by only $55.78 \%$ decrease in rat paw edema. ${ }^{[37-38]}$

Anti-obesity activity: - Charan Singh et al. (2015) studied the estimation of anti obesity activity of ethanolic root extract of Boerhaavia diffusa. The focus of anti-obesity management has moved toward the herbal drugs. The On the basis of investigational data obtained, it was studied that the root extract showed significant antiobesity action. The study indicated with the aim of the ethanolic extract from the whole plant of Boerhaavia diffusa revealed significant anti-obesity action.

Antioxidant activity: Satheesh and Pari demonstrated that administration of Boerhaavia diffusa leaf extract for 4 weeks resulted in a hydro - alcoholic extract exhibits significant antioxidant activity. Manu et al. (2007) investigated about the increased effect of Punarnavine on the cell-mediated immune (CMI) response compare to metastatic progression of B16F-10 melanoma cells in mice. Mili et al. (2007) evaluated the antioxidant activity and genoprotective effects. Venkatesh et al. (2013) performed screening of hepatoprotective and antioxidant activity of alcoholic and aqueous extracts of Boerhaavia diffusa and Anisochilus carnosus. Thioacetamide 


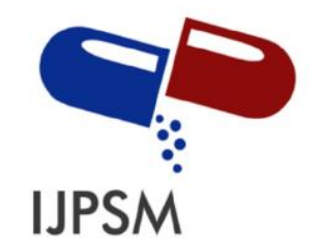

\section{Rekha Gour, Int. Journal of Pharmaceutical Sciences and Medicine (IJPSM), Vol.6 Issue. 4, April- 2021, pg. 25-41}

ISSN: 2519-9889

Impact Factor: 3.426

induced hepatotoxicity in rats was used to screen hepatoprotective activity. These extracts of Boerhaavia diffusa shows hepatoprotective and antioxidant activity in a dose dependent manner. ${ }^{[23]}$

\section{Clinical trials: -}

Supporting the preclinical studies several clinical studies were carried out in Boerhaavia diffusa extracts. These are as follows

\section{$>$ In treatment of pulmonary tuberculosis:}

Pulmonary Tuberculosis is a widespread and frequently deadly infectious disease. Its treatment is difficult and requires long courses of multiple antibiotics. So it's necessary to found alternative methods to curb this problem. Surya et al. proved the extract of Boerhaavia diffusa used in the treatment of 25 patients of pulmonary tuberculosis as well as chemotherapy. Results showed that the no. of patients who received Punarnava along with chemotherapy be evidence for significantly faster and earlier clinical recovery. ${ }^{[39]}$

\section{Anthelminthic activity:}

Singh and Udupa evaluated that dried root powders of Boerhaavia diffusa showed therapeutic effectiveness against soil - transmitted helminth infections. They found children or adults suffering from helminth infection became worm-free within five days when administered orally with the powder. ${ }^{[40]}$

\section{CONCLUSION}

Boerhaavia diffusa linn is a well-known medicinal plant that is frequently prescribed in various indigenous systems of medicine such as Ayurveda and Unani. Throughout the millennia Boerhaavia diffusa plant has developed into a phenomenon medicinal plant having an excess of chemical constituents helpful against a many number of disorders. This plant finds extensive importance in the traditional herb based preparations in the worldwide. Boerhaavia diffusa plant gets utilize as a cure for 22 disorders in Ayurvedic and Unani. Boerhaavia diffusa plant also finds 23 utilizes for the treatment of several clinical conditions in Brazil pharmacopeia. The plant has a number of traditional uses for ameliorating multiple diseases, which were further supported by several pharmacological and clinical studies detailing the specific bioactivity of extracts of the plant. Although there are gaps in the studies carried out so far, which need to be associated in order to develop the full medicinal potential of Boerhaavia diffusa, it is still very comprehensible that this is a plant with incredible extensive use nowadays and also with extraordinary potential for the future research. This review is the collection of the studies conducted on various aspects on Boerhaavia diffusa by different authors and the traditional healers to provide useful information for future scope of research and for conservation of this valuable species. 


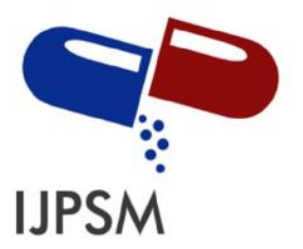

\section{Rekha Gour, Int. Journal of Pharmaceutical Sciences and Medicine (IJPSM), Vol.6 Issue. 4, April- 2021, pg. 25-41}

ISSN: 2519-9889

Impact Factor: 3.426

\section{REFERENCES}

[1]. Bent S., Ko R. commonly used herbal medicines in the United States: a review. The American Journal of Medicine, 2004; 116(7): 478-85.

[2]. Dwivedi S., Srivastava S., Dubey D., Kapoor S., Jain S., Status Conservation Strategies of Herbal Oral Contraceptives. Planta Indica, 2007; 3(1): 5-8.

[3]. Veeresham C., Natural products derived from plants as a source of drugs. Journal of Advanced Pharmaceutical Technology \& Research, 2012; 3(4): 200-20.

[4]. Dwivedi S., Dwivedi A., Dwivedi SN., Folklore uses of some plants by the tribals of Madhya Pradesh with special reference to their conservation. Ethanobotanical Leaflets, 2008; 12: 763-771.

[5]. Anonymous Medicinal Plants of India. India Council of Medical Research, New Delhi, 1987.

[6]. Anonymous Indian medicinal plants: A sector study. Ethno botany, 1997; 17: 11.

[7]. SARS, clinical trials on treatment using a combination of traditional Chinese medicine, western medicine, Geneva: WHO, 2003; 53-61.

[8]. Akeree O., Summary of WHO guidelines for the assessment of herbal medicines. Herbal gram, 1993; 28: 13-19.

[9]. Bulletin of the WHO, Research guidelines for evaluating the safety, efficacy of herbal medicine, Geneva, 1993; 186.

[10]. Bulletin of the WHO, Regulatory situation of herbal medicines, Geneva, 1998; 1-43.

[11].WHO, general guidelines for methodologies on research, evaluation of traditional medicine, World Health Organization, Geneva, 2000?

[12].Narayan D., Prajapati P., Argo's colour atlas of medicinal plants, Hardcover publisher agrobios, 2003; 1: 1-3.

[13].Pey MM, Rastogi S., Rawat AKS, Indian traditional ayurvedic system of medicine, nutritional supplementation, evidence-based complementary, alternative medicine. Article ID 376327, 2013; 12.

[14].Verma V., Kasera PK, Mohammed S., Conservation of desert medicinal plants, cultivating practices of Asparagus racemes: A potential bio resource, In Indian folk medicine Ed. P. C. Trivedi, Pointer publication, Jaipur. 2007; 299-302.

[15].Balakrishnan BR, Thenmozhi S., Dwivedi S., Comparative Physicochemical analysis of seeds of Guizotia abyssinica (L.f.) Cass. As influenced by varying concentration of phytohormones. Pharma Chem., 2010; 9: 21-23.

[16]. Bakhru HK., Herbs that heals Natural remedies for good health. Orient paperbacks, 1998; 1: 17-18.

[17].Mahesh A.R., Harish Kumar, Ranganath M.K., Detail Study on Boerhaavia Diffusa Plant for its Medicinal Importance- A Review. Research Journal of Pharmaceutical Sciences, 2012; 1(1): 28-36.

[18].Pranati Nayak, Thirunavoukkarasu M., A review of the plant Boerhaavia diffusa: its chemistry, pharmacology and therapeutical potential. The Journal of Phytopharmacology, 2016; 5(2): 83-92.

[19].Laxmi Banjare, Anand kumar Prasad and Naik M.L., Boerhaavia diffusa from Traditional Use to Scientific Assessment - A Review. International Journal of Pharmaceutical \& Biological Archives 2012; 3(6):1346-1354.

[20].Somenath Ghosh, Rai S.K., Boerhaavia diffusa: One plant with many functions. International Journal of Green Pharmacy, 2018; 12 (3): 442-448. 


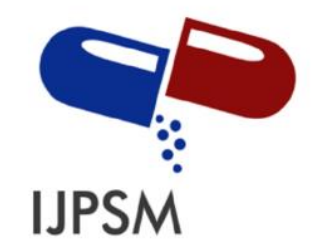

\section{Rekha Gour, Int. Journal of Pharmaceutical Sciences and Medicine (IJPSM), Vol.6 Issue. 4, April- 2021, pg. 25-41}

ISSN: 2519-9889

Impact Factor: 3.426

[21].Kanagavalli U., Mohamed Sadiq A., historical review of Indian divine herb boerhaavia diffusa linn and its medicinal importance. World journal of pharmacy and pharmaceutical sciences, 2018; 7(9): 577-594.

[22].Rajesh Kumar, Gautam S., Singh K.D., Kumar P., Pharmacological properties of Boerhaavia diffusa: A review. International Conference on Food Security and Sustainable Agriculture, 2018; 1: 72-80.

[23].Nishi Saxena and Ameeta Argal, Physical and Phytochemical Screening of Boerhaavia diffusa L. Roots. Research and reviews: journal of pharmacognsoy and phytochemistry, 2014; 2(1): 01-04.

[24].Mayur Chandranshu Mishra, Shastri Prasad Shukla, Scientific evaluation of punarnawa (boerhaavia diffusa linn.) -root. European journal of biomedical and pharmaceutical sciences, 2017; 4(9): 636-641.

[25].Sahu A. N., Damiki L., Nilanjan G., Dubey S., Plant Review Phytopharmacological Review of Boerhaavia diffusa Linn.(Punarnava). Pharmacognosy Reviews [Phcog Rev.] -Supplement, 2008; 2(4): 14-22.

[26].Shikha Mishra, Vidhu Aeri and Praveen K. Gaur, Phytochemical, Therapeutic, and Ethno pharmacological Overview for a Traditionally Important Herb: Boerhaavia diffusa Linn. Hindawi Publishing Corporation BioMed Research International Volume, 2014; 01-19.

[27].Praveen Kumar Posa Krishnamoorthy and Sivanandham Muthukumaran, Isolation, purification and characterization of boeravinone b from Boerhaavia diffusa linn. International research journal of pharmacy, 2017, 8 (11): $140-145$.

[28]. Santhosha D., Ramesh A., Sravan Prasad M., review article on Punarnava plant. Research Journal of Pharmaceutical, Biological and Chemical Sciences, 2011; 2 (4): 427-436.

[29].Juna Beegum G.R., Suhara Beevy S., Sugunan V.S., Qualitative Phytochemical Screening and GC-MS Analysis of Boerhaavia diffusa L. International Journal of Emerging Technology and Advanced Engineering, 2014; 4(7): 317 324.

[30].Gulshan Chaudhary and Prem Kumar Dantu, Morphological, phytochemical and pharmacological, studies on Boerhaavia diffusa L. Journal of Medicinal Plants Research, 2011; 5(11): 2125-2130.

[31].Krishna Murti, vijay lambole, antidiabetic and antihyperlipidemic activity of roots of boerhaavia diffusa on streptozotocin induced diabetic rats. Pharmacology online, 2011; 1: 15-21.

[32].Mohan Nisha, Balakrishnan Nair Vinod, Evaluation of Boerhaavia erecta L. for potential antidiabetic and antihyperlipidemic activities in streptozotocin-induced diabetic Wistar rats. Future Journal of Pharmaceutical Sciences, 2018; 4:150-155.

[33].Mehrotra S., Mishra K.P., Mourya R., immunomodulation by ethanolic extract of boerhaavia diffusa roots, international immuno pharmacology, 2002; 2(7): 987-996.

[34].Sourav Das, Antimicrobial activity study of ethanolic extract of Boerhaavia diffusa whole plant. International journal of pharmacy \& life sciences, 2012; 3(10): 1-4.

[35].Venkatesh P., Dinakar A., Senthilkumar N., screening of hepatoprotective and antioxidant activity of alcoholic and aqueous extracts of boerhaavia diffusa and anisochilus carnosus. International Journal of Pharmacy and Pharmaceutical Sciences, 2013; 5(2): 208-211.

[36].Shameela S., Shamshad S., Indira Priyadarsini A., Evaluation of boerhaavia diffusa for hepatoprotective activity in experimental wistar rats. International Journal of Pharmacy and Biological Sciences, 2015; 5(1): 115-122. 


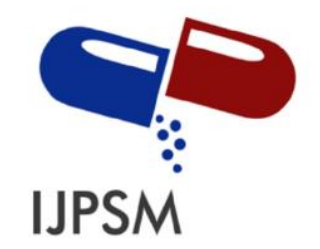

\section{Rekha Gour, Int. Journal of Pharmaceutical Sciences and Medicine (IJPSM), Vol.6 Issue. 4, April- 2021, pg. 25-41}

ISSN: 2519-9889

Impact Factor: 3.426

[37].Manisha Gharate \& Veena Kasture, Evaluation of anti-inflammatory, analgesic, antipyretic and antiulcer activity of Punarnavasava: an Ayurvedic formulation of Boerhaavia diffusa. Orient Pharm Exp Med, 2013; 13: 121-126.

[38].Santhoshkumar Muthu, sivaganesh M., shibi ashir, anti-inflammatory effect of ethanolic extract of Boerhaavia diffusa leaves in wistar rats. Malaya journal of biosciences 2014, 1(2):76-85.

[39].Surya K., Agnihotri M.S., Dixit K.S., clinical evaluation of Boerhaavia diffusa as an adjuvant in the treatment of pulmonary tuberculosis. The Journal of Phytomedica, 2001; 2(1\&2): 89-94.

[40].Singh R.H., Udupa K.N., studies on the Indian indigenous drug punarnava (Boerhaavia diffusa linn). Part IV: preliminary controlled clinical trial in nephrotic syndrome. J. Res. Ind. Med., 1972; 7: 28-33.

[41].Sibi P.Ittiyavirah, Reshma Ghosh, Cognitive effects of ethanolic extract of Boerhaavia diffusa and its silver nanoparticles in ethanolic dementia model. The Journal of Phytopharmacology, 2016; 5(5): 185-189.

[42]. Sandhya k. Desai, Soniya M. Desai, Navdeep S., antistress activity of boerhaavia diffusa root extract and a polyherbal Formulation containing boerhaavia diffusa using cold restraint stress model. International journal of pharmacy and pharmaceutical sciences, 2011;3(1): 130-132.

[43].Surendra K. Pareta, Kartik C. Patra, Aqueous extract of Boerhaavia diffusa root ameliorates ethylene glycolinduced hyperoxaluric oxidative stress and renal injury in rat kidney. Pharmaceutical Biology, 2011; 49(12): 1224-1233.

[44]. Charan Singh, Tarun Virmani and Jyoti Gupta, antiobesity potential of boerhaavia diffusa on animal model of obesity. World Journal of Pharmaceutical Research, 2015; 4(11): 1196-1206.

[45].Vandana. S. Nade and laxman. A. Kawale, Antihypertensive potential of boerhaavia diffusa 1. In adrenalineinduced hypertensive model. International Journal of Experimental Pharmacology, 2015; 5(1): 24-30.

[46].Salman Khan M., Irfan A. Ansari and Saheem Ahmad, Chemotherapeutic potential of Boerhaavia diffusa Linn: A review. Journal of Applied Pharmaceutical Science, 2013; 3 (01): 133-139.

[47].Majgaine, Shweta and Verma D. L., Phytochemical analysis of Boerhaavia diffusa along the altitudinal gradients from foot hill to hot temperate valley of kumaun Himalaya. Journal of Global Biosciences, 2017; 6(1): 4713-4726.

[48].Kuldeep Rajpoot, Mishra R. N., Boerhaavia diffusa roots (Punarnava mool) - Review as Rasayan (Rejuvenator / Antiaging). International Journal of Research in Pharmaceutical and Biomedical Sciences, 2011; 2(4): 1451-1460.

[49]. Surendra K. Pareta, Kartik C. Patra, Ranjeet Harwansh, Protective Effects of Boerhaavia Diffusa Against Acetaminophen-Induced nephrotoxicity in Rats. Pharmacologyonline, 2011; 2: 698-706.

[50].Rao K. Nalamolu, Krishna M. Boini, Effect of chronic administration of Boerhaavia diffusa Linn. Leaf extract on experimental diabetes in rats. Tropical Journal of Pharmaceutical Research, June, 2004; 3 (1): 305-309.

[51].Rijuraj M.P. and Chandralekha C. T., Comparison of mitotic effect of aqueous, alcohol and petroleum ether extract of the leaves of boerhaavia diffusa on root meristem of allium cepa. International Journal of Advanced Research, 2017; 5(3), 379-388.

[52].Remya M. J., Shahul Hameed A. and K. Sujathan K., Cytotoxicity of punarnava (boerhaavia diffusa 1.) In breast cell line. International Journal of Ayurveda and Pharmacy Research, 2018; 6(6): 1-5. 